\title{
PENDEKATAN DAKWAH JAMA'AH TABLIGH DALAM MENINGKATKAN KETAATAN BERAGAMA MASYARAKAT
}

\author{
Yudi Andrian \\ Institut Agama Islam Agus Salim Metro \\ Jl. Brigjend. Sutiyoso No. 7, Kota Metro, 34111, Lampung \\ yudiandrian@gmail.com
}

\begin{abstract}
Jama'ah Tabligh is one of the da'wah movements that has sincerity to invite the community to obey Allah by practicing religion perfectly in accordance with the example of the king of the Prophet, especially inviting to practice the five daily prayers in congregation. Approach Jama'ah Tabligh by performing (silaturahim) from house to house which in this case uses a psychological approach to invite (persuasive), invites to obey God. Educational approach by holding religious lectures (bayan) on the importance of faith in good deeds in the mosque, the efforts of Jama'ah Tabligh by using this method have not been fully influential because there is another approach which is forgotten by Jama'ah Tabligh, which is a cultural approach. The Tabligh Jama'ah approach in increasing religious adherence to the community by visiting Muslim brothers from house to house (jaulah), conveyed the importance of faith and good deeds in the information majlis (Bayan), and ta'lim has not been influential especially in the effort to invite the public to obey Allah SWT, follow the way of the Prophet Muhammad. Because Jama'ah Tabligh in the approach taken has not been able to adjust to the culture of the community in accordance with the conditions of the community and Jama'ah Tabligh in his da'wah approach forgets an approach, namely the Cultural approach.
\end{abstract}

Keywords: Da'wah approach, Jama'ah Tabligh

\begin{abstract}
Abstrak
Jama'ah Tabligh adalah salah satu gerakan dakwah yang memiliki kesungguhan untuk mengajak masyarakat taat kepada Allah dengan menjalankan agama secara sempurna sesuai dengan contoh dari baginda Rasulullah Saw, khususnya mengajak mengamalkan shalat lima waktu secara berjama'ah. Pendekatan Jama'ah Tabligh dengan ber-jaulah (silaturahim) dari rumah ke rumah yang dalam hal ini menggunakan pendekatan psikologis untuk mengajak (persuasif), mengajak untuk taat kepada Allah. Pendekatan pendidikan dengan mengadakan memceramah agama (bayan) tentang pentingnya iman amal shalih ta'lim di masjid, upaya Jama'ah Tabligh dengan menggunakan cara ini belum sepenuhnya berpengaruh karena ada pendekatan lain yang dilupakan oleh Jama'ah Tabligh yaitu pendekatan budaya. Pendekatan Jama'ah Tabligh dalam meningkatkan ketaatan beragama mayarakat dengan cara mengunjungi saudara muslim dari rumah ke rumah (ber-jaulah), menyampaikan tentang pentingnya iman dan amal shalih dalam majlis penerangan (Bayan), dan ta'lim belum berpengaruh terutama dalam usaha mengajak masyarakat untuk taat kepada Allah SWT, mengikuti cara Rasulullah SAW. Karena Jama'ah Tabligh dalam pendekatan yang dilakukan belum dapat menyesuaikan dengan kebudayaan masyarakat yang sesuai dengan kondisi masyarakat dan Jama'ah Tabligh dalam pendekatan dakwahnya melupakan suatu pendekatan, yaitu pendekatan Budaya.
\end{abstract}

Kata Kunci : Pendekatan Dakwah, Jama'ah Tabligh 


\section{Pendahuluan}

Manusia sebagai makhluk social memiliki tujuan dan prinsip, dan dalam kehidupan antar sesama manusia terdapat suatu hubungan yang tidak dapat di pisahkan terutama dalam hal muamalah. Manusia satu membutuhkan manusia lainnya untuk memenuhi kebutuhan hidupnya. Dalam perjalanan manusia kepada kebahagian hidup di dunia dengan berkeluarga, memiliki pendamping hidup dan keturunan. ${ }^{1}$ Seorang manusia yang bertanggung jawab dan memiliki agama yang kokoh akan mencari berbagai cara yang halal untuk memenuhi kebutuhan hidup dirinya dan keluarganya.

Pendekatan dakwah ialah penentuan strategi dan pola dasar dan langkah dakwah yang didalamnya terdapat metode dan teknik untuk mencapai tujuan dakwah. ${ }^{2}$ Pendekatan Dakwah dalam buku Ilmu Dakwah karya Moh. Ali Aziz adalah titik tolak atau sudut pandang kita terhadap proses dakwah. Umumnya, penentuan pendekatan didasarkan pada mitra dakwah dan suasana yang mencakupinya. ${ }^{3}$

Pendekatan dakwah yang di jadikan titik tolak oleh Jama'ah Tabligh dalam berdakwah adalah dengan mengunjungi saudara muslim dari rumah ke rumah atau yang sering disebut dengan ber-jaulah (silaturahim), mengajak untuk taat kepada Allah Swt dengan mengajak shalat berjama'ah di masjid, mengadakan ceramah agama atau majlis penerangan (bayan) tentang pentingnya iman, amal shalih dan mengadakan ta'lim.

Jama'ah4 Tabligh merupakan ummat islam yang sama dengan ummat islam lainnya, yang berbeda adalah mereka memiliki fikir dan risau bagaimana agar seluruh ummat manusia dapat taat kepada Allah Swt dan dapat melaksanakan apa yang di contohkan oleh Rasulullah Saw, dengan membuat suatu usaha mengajak dan menyeru manusia kembali kepada fitrahnya, yaitu agama. Jama'ah Tabligh menyeru manusia kepada fitrahnya yaitu agama, dengan cara berdakwah yang dimulai dari keluarga, ummat dikampungnya dan ummat diseluruh alam.

Jama'ah Tabligh adalah jama'ah yang sangat intens melakukan dakwah. ${ }^{5}$ Dakwah yang disampaikan menyesuaikan dengan cara yang dilakukan oleh para Nabi As. dengan cara ber-jaulah (silaturahmi) mendatangi ummat nya dari rumah ke rumah, mengajak ummat nya untuk taat kepada Allah dengan mengajak mengamalkan agama secara sempurna (kaffah). Jama'ah Tabligh dalam pendekatan dakwah nya juga menggunakan majlis penerangan (bayan) tentang pentingnya agama, usaha atas agama.

1 Muhamad Bisri Mustofa, Hukum Nafkah Terhadap Keluarga pada Gerakan Dakwah Jama'ah Tabligh, Jurnal Nizham, Vol. 7, No. 1 (2019), h. 1

2 Rini Setiawati, Ilmu Dakwah, (Bandar Lampung : PUSIKAMLA, 2009), Cet. Ke-1, h. 68

${ }^{3}$ Moh. Ali Aziz, Ilmu Dakwah, (Jakarta : Kencana, 2009), Cet. Ke-2, h. 347

${ }^{4}$ Jama'ah adalah orang-orang yang memiliki niat, fikir, ucapan, usaha, maksud, dan tujuan yang sama dalam mengamalkan perintah Allah Swt sesuai yang dicontohkan oleh Rasulullah SAW. Seperti shalat berjama'ah di masjid, semua orang melakukan rukun dan tertib yang sama, tanpa ada perbedaan status, jabatan, golongan, suku, warna kulit, dan sebagainya. Sekelompok orang banyak belum tentu disebut Jama'ah, sebagaiman orang-orang yang berada di pasartidak bisa disebut Jama'ah pasar. Sebab niat, fikir, kerja, maksud dan tujuan orang yang ada di pasar berbeda-beda. (Dikutip dalam An Nadhr Muhammad Ishaq Shahab, Khuruj fii sablilillah : Sarana Tarbiyyah Ummat Dalam Rangka Membentuk Sifat Imaniyah, (Bandung : Pustaka Ramadhan, 2007), Cet. ke-7, Jilid 1, h. 43).

${ }^{5}$ Khusniati Rofiah, Dakwah Jama'ah Tabligh E Eksistensinya Di Mata Masyarakat, (Ponorogo : STAIN Press, 2010), Cet. Ke-1, h. 78 
Ketaatan berasal dari kata "taat" adalah patuh kepada Tuhan. ${ }^{6}$ Ketaatan yang dimaksud disini adalah tunduk, patuh nya seorang hamba kepada Allah Swt. Ketaatan seorang muslim kepada Allah Swt. dengan landasan imaniyah (kepercayaan), ubudiyah (ibadah), muamalah (jual beli), muasyarah (berhubungan), dan akhlak. Ketaatan seorang muslim dapat diukur dengan kelima hal diatas.

Ketaatan beragama yang dimaksud penulis adalah kepatuhan seorang muslim terhadap agama yang terimplementasi pada pelaksanaan shalat berjama'ah lima waktu, dan lima aspek yang dijadikan indikator ketaatan beragama seseorang, yaitu : keyakinan (imaniyah), ibadah (ubudiyah), jual beli (muamalah), berhubungan (muasyarah), dan akhlak.

Berdasarkan definisi diatas maka yang dimaksud penulis adalah tentang pendekatan dakwah yang dilakukan oleh Jama'ah Tabligh dalam meningkatkan ketaatan dalam beragama masyarakat adalah pada pelaksanaan shalat berjama'ah lima waktu di masjid. Dengan indikator penelitian tertuju pada ketaatan beragama masyarakat dalam mengimplementasikan keyakinan (imaniyah), ibadah (ubudiyah), jual beli (muamalah), bermasyarakat (muasyarah), dan akhlak dalam kehidupan sehari-hari.

\section{Pendekatan Dakwah Pengertian}

Pendekatan (nahiyah) dalam kamus Al-Munawir sebagaimana dikutip dalam buku Ilmu Dakwah karya Moh. Ali Aziz (Jakarta : 2009), nahiyah berasal dari pembentukan kata nahaa-yanhuu-nahwan yang bisa diartikan arah (al-jihah); sisi (aljanib); jalan atau cara (al-thariqah); tujuan (al-qashd); sama (al-mitsl); macam (al-naw'); ukuran (al-miqdar); bagian (al-qism); dan daerah (al-shufh). ${ }^{7}$ Dari makna-makna ini, pendekatan atau al-nahiyah terlihat lebih luas dan lebih umum, sehingga ia relevan untuk diterjemahkan dengan cara melihat (how to look).

Dalam buku Metodologi Penelitian Dakwah karya Asep Saeful Muhtadi dan Agus Ahmad Safei, makna istilah "pendekatan" sama dengan metodologi, yaitu sudut pandang atau cara melihat dan memperlakukan sesuatu yang menjadi perhatian atau masalah yang dikaji. ${ }^{8}$ Jadi, yang dimaksud pendekatan dakwah ialah penentuan strategi dan pola dasar dan langkah dakwah yang didalamnya terdapat metode dan teknik untuk mencapai tujuan dakwah. ${ }^{9}$ Pendekatan Dakwah dalam buku Ilmu Dakwah karya Moh. Ali Aziz, pendekatan adalah titik tolak atau sudut pandang kita terhadap proses dakwah.

Umumnya, penentuan pendekatan didasarkan pada mitra dakwah dan suasana yang mencakupinya.10 Dengan kondisi dan suasana masyarakat yang berbeda-beda, Jama'ah Tabligh dalam berdakwah menggunakan Pendekatan dengan cara ber - Jaulah (silaturahmi) dari rumah ke rumah mengunjungi saudara muslim menyampaikan kebesaran Allah Swt. Selain dengan ber-Jaulah (Silaturahim), pendekatan dakwah yang dilakukan Jama'ah Tabligh adalah membuat majlis penerangan (bayan) menyampaikan tentang pentingnya iman dan

\footnotetext{
6 Dessy Anwar, Kamus Lengkap Bahasa Indonesia Terbaru, (Surabaya : Amelia), h. 18

7 Moh. Ali Aziz, Ilmu Dakwah, (Jakarta : Kencana, 2009), Cet. Ke-2,h. 346

8 Asep Saeful Muhtadi, Agus Ahmad Safei, Metodologi Penelitian Dakwah, (Bandung : Pustaka Setia, 2003), Cet. Ke-1, h. 107

9 Rini Setiawati, Ilmu Dakwah, (Bandar Lampung : PUSIKAMLA, 2009), h. 68

10 Moh. Ali Aziz, Ilmu Dakwah, (Jakarta : Kencana, 2009), Cet. Ke-2, h. 347
} 
amal shalih di Masjid. Pendekatan dakwah dapat dibagi menjadi dua bentuk, yaitu: Pendekatan Sosial dan pendekatan Budaya. Setiap pelaksanaan dakwah dengan unsurnya harus menggunakan pendekatan (approach) yang tepat, seperti dakwah yang dilaksanakan oleh Jama'ah Tabligh.

Drs. Sahudi Siroj mengemukakan 3 macam pendekatan dakwah bagi masyarakat Indonesia : Pendekatan Kebudayaan, Pendekatan Pendidikan, Pendekatan Psikologis. 11

a. Prinsip Dari Pendekatan Dakwah

1. Pendekatan (approach) dakwah senantiasa memperlihatkan dan menempatkan penghargaan yang tinggi atas manusia dengan menghindari prinsip-prinsip yang akan membawa kepada sikap pemaksaan kehendak.

2. Peran hikmah dan kasih sayang adalah merupakan salah satu faktor paling dominan dalam proses penyampaian idea-idea dalam komunikasi dakwah tersebut.

3. Pendekatan (approach) dakwah yang bertumpu pada human oriented menghargai keputusan final yang diambil oleh pihak komunikan (mad'u) dan karenanya dakwah merupakan penyampaian idea-idea secara demokratis.

Pedekatan (approach) dakwah yang didasarkan atas hikmah dan kasih sayang itu, dapat memakai segala alat yang dibenarkan menurut hukum sepanjang hal tersebut tetap menghargai hak-hak manusia itu sendiri. ${ }^{12}$

b. Fungsi Pendekatan Dalam Dakwah

Pedekatan (approach) adalah sudut pandang, penentuan langkah awal yang didalammnya terdapat metode dan teknik. Dalam hal ini fungsi pendekatan diperlukan dalam berbagai bidang. Pada umumnya pendekatan merupakan sudut pandang atau cara yang tertuju kepada suatu objek dakwah (mad'u). Dengan adanya pedekatan maka dakwah yang dilaksanakan akan lebih dinamis dan terfokus. Seperti dakwah yang disampaikan kepada para fakir miskin, akan lebih berfungsi dengan pendekatan dakwah melalui ekonomi. Sebagaimana dilakukan oleh aliran Islam tertentu yamg lebih mengedepankan keperluan jasmani sebagai pendekatan dakwahnya.

Berbeda dengan jam'ah tabligh yang pendekatannya dakwahnya dengan mengajak masyarakat untuk taat kepada Allah dan Rasulullah Saw. dan berdakwah dengan harta, diri dan waktu di jalan Allah Swt. sebagai sarana memperbaiki (islah) diri. Dari beberapa pendekatan yang di jelaskan diatas dapat disimpulkan beberapa fungsi pendekatan dalam dakwah :

1. Sebagai sarana mempermudah dakwah yang dilakukan dan mengontrol kondisi masyarakat yang beraneka ragam dengan menggunakan salah satu pedekatan dakwah yang telah ada.

2. Sebagai sarana memfokuskan tujuan dari dakwah yang dilaksanakan agar lebih tepat sasaran kepada mad'u.

3. Sebagai sarana pedoman dalam menganalilis dakwah seperti apa yang akan dilakukan terhadap mad'u.

\footnotetext{
11 Rini Setiawati, Op.cit, h. 69

12 Rini Setiawaati, Ibid, h. 69
} 
c. Beberapa Pendekatan dalam Dakwah

Dibawah ini terdapat dua dimensi dalam dakwah sebagai landasan dalam pendekatan dakwah, Dimensi Kerisalahan (bi ahsan al-qawl), yaitu penyampaian pesan kebenaran. Dimensi Kerahmatan (bi ahsan al-amal), yaitu pengaplikasian nilai kebenaran. Dari kedua dimensi diatas dapat menjadi landasan dalam pendekatan dakwah. Oleh sebab itu pendekatan dakwah dengan dilandasi dua dimensi diatas terbagi menjadi 4 yaitu:

1. Pendekatan Dakwah Struktural

Dakwah struktural adalah kegiatan dakwah yang menjadikan kekuasaan, birokrasi, kekuatan politik sebagai alat untuk memperjuangkan Islam. Dakwah structural bersifat top-down, hingga dalam prakteknya aktivis dakwah struktual bergerak mendakwahkan ajaran Islam dengan memanfaatkan struktur politik, maupun ekonomi guna menjadikan Islam sebagai Ideologi Negara, sehingga nilai-nilai Islam mengenjewantah dalam kehidupan berbangsa dan bernegara. Pendekatan ini untuk membangun kehidupan berbangsa dan bernegara yang sejahtera dan relijius, dakwah bisa menggunakan pendekatan structural atau pendekatan politik. Harus ada para politikus dalam legislatif yang membuat undang-undang untuk kelangsungan kehidupan yang lebih Islami. Dibutuhkan pula politikus dalam eksekutif yang menjalankan pemerintahan berdasarkan produk hukum tersebut. ${ }^{13}$

Pendekatan ini melalui jalur structural formal misalnya pemerintahan. Hal yang pernah ditempuh oleh Prof. DR. Amien Rais, dengan Ikatan Cendekiawan Muslim Indonesia (ICMI). ${ }^{14}$ Berbeda dengan Jama'ah Tabligh yang tidak memiliki struktural, karena amal yang dilaksanakan ini semata-mata untuk memperbaiki diri sendiri (islah) dan tidak memiliki tujuan untuk memajukan atau mengajak kepada suatu golongan, firkoh, sekte, aliran, atau organisasi tertentu. ${ }^{15}$ Tetapi untuk satu tujuan yaitu mengajak manusia taat kepada Allah dan dapat mengamalkan segala perintahnya dan menjauhi larangan nya dengan mengikuti apa yang di contohkan Rasulullah Saw. Lalu mengajak berkorban harta, diri dan waktu untuk mentablighkan agama kepada ummat seluruh alam. Itulah yang menjadi tujuan jama'ah Tabligh mengajak manusia untuk sama-sama taat kepada Allah Swt. dan RasulNya.

2. Pendekatan Dakwah Kultural

Pendekatan Kultural adalah pengembangan dakwah melalui jalur kultural nonformal, misalnya melalui pengembangan masyarakat, kebudayaan, social, dan bentuk nonformal lainnya. Hal ini pernah dikembangkan oleh KH.Abdurrahman Wahid dengan Nahdhatul Ulama (NU). ${ }^{16}$

\footnotetext{
13 Moh. Ali Aziz, Op.cit, h. 348

14 Samsul Munir Amin, Ilmu Dakwah, (Jakarta : Amzah, 2009), Cet. Ke-1, h. 109

15 Rizal, Penanggung Jawab Holaqoh Jama'ah tabligh, Wawancara, tanggal 23 Juni 2014

16 Samsul Munir, Loc.cit, h. 109
} 
Dakwah kultural adalah pertama dakwah yang bersifat akomodatif terhadap nilai budaya tertentu secara inovatif dan kreatif tanpa menghilangkan aspek substansial keagamaan, kedua menekankan pentingnya kearifan dalam memahami kebudayaan komunitas tertentu sebagai sarana dakwah. Pendekatan kultural atau social-budaya dengan membangun moral masyarakat melalui kultur mereka, misalnya dengan memberdayakan ekonomi masyarakat, memberikan pendidikan yang memadai untuk membentuk sumber daya manusia yang berkualitas dan sebagainya. ${ }^{17}$ Jadi, Dakwah Kultural adalah dakwah yang bersifat buttomup dengan melakukan pemberdayaan kehidupan beragama berdasarkan nilai-nilau spesifik yang dimiliki oleh sasaran dakwah. Menurut Muhammad Shulton bahwa dakwah kultural adalah aktivitas dakwah yang menekankan Islam kultural. Islam kultural adalah salah satu pendekatan yang berusaha meninjau kembali kaitan doktrinal yang formal antara Islam dan politik atau Islam dan Negara. ${ }^{18}$

3. Pendekatan Sosial

Pendekatan ini didasarkan atas pandangan bahwa penerima/mitra dakwah adalah manusia yang bernaluri sosial serta memiliki keterkaitan dan ketergantungan dengan orang lain. Interaksi sosial manusia ini meliputi semua aspek kehidupan yaiu interaksi budaya, pendidikan, politik, dan ekonomi. Oleh karena itu, pendekatan sosial ini meliputi: Pendekatan Pendidikan, Pendekatan Budaya, Pendekatan Politik, Pendekatan Ekonomi. ${ }^{19}$ Dengan adanya pendekatan dibidang sosial ini maka aspek permasalahan dakwah dimasyarakat dapat ditanggulangi dengan beberapa pendekatan dakwah diantaranya, yaitu :

a) Pendekatan Pendidikan

Pendidikan merupakan kebutuhan dan sekaligus tuntutan masyarakat, baik pendidikan formal, nonformal, maupun informal. Lembaga-lembaga pendidikan peranannya dalam pembentukan kecerdasan yang bersangkutan, kedewasaan wawasan serta pembentuka manusia moralis yang berakhlakul karimah sebagai objek maupun subjek pembangunan manusia seutuhnya. Contohnya di dirikannya taman pendidikan agama (TPA), sekolah-sekolah Islam Terpadu, pondok pesantren, dan lain-lain.

b) Pendekatan Budaya

Setiap masyarakat memiliki budaya sebagai karya mereka sekaligus sebagai pengikat kebutuhan mereka. Para Wali Songo, yang memandang bangsa Indonesia dengan budaya yang tinggi secara tepat menggunakan budaya dalam dakwahnya, dan ternyata membawa hasil. Dakwah dengan pendekatan budaya ini dilakukan dengan mengadaptasi budaya masyarakat tertentu untuk menanamkan nilai-nilai agama dalam budaya.

4. Pendekatan Politik

17 Moh. Ali Aziz, Op.cit, h. 348

18 Muhammad Sulthon, Desain Ilmu Dakwah Kajian Ontologis, Epistimologi dan Aksiologis, (Yogyakarta : Walisongo Press, 2003), h. 34

${ }^{19}$ Rini Setiawati, Ibid, h. 70 
Banyak hal yang tidak dapat diselesaikan dengan pendekatan lain kecuali dengan pendekatan politik, melalui kekuasaan. Bahkan hadis Nabi secara khusus memerintahkan amr ma'ruf nahi munkar dengan "fal yughoyyihu biyaadihi" artinya melakukan nahi munkar tersebut dengan kekuasaan (politik) pada penguasa. Oleh sebab itu berdirilah partai-partai Islami yang melakukan pendekatan dalam berdakwahnya di bidang politik. Dengan adanya pendekatan politik maka setiap lini pemerintahan akan di landasi oleh landasan agama. Seperti dalam lembaga legislatif, eksekutif, dan yudikatif berlandaskan pada agama.

5. Pendekatan Ekonomi

Ekonomi termasuk kebutuhan asasi dalam kehidupan setiap manusia. Kesejahteraan ekonomi memang tidak menjamin suburnya kehidupan keimanan seseorang, akan tetapi sering kali kefakiran akan membawa seseorang pada kekufuran, adalah merupakan realitas yang banyak di temukan. Pendekatan ekonomis dalam pelaksanaan dakwah pada masyarakat yang minus ekonomi untuk meningkatkan kesejahteraan hidup atau disebut dengan dakwah bil hal mutlak dilakukan sebagai pendukung stabilitas keimanan dan kontinuitas ibadah masyarakat.

6. Pendekatan Psikologis

Pendekatan ini meliputi dua aspek:

Citra pandang dakwah terhadap manusia sebagai makhluk yang memiliki kelebihan dibanding dengan makhluk lainnya. Oleh karena itu, mereka harus dihadapi dengan pendekatan persuasif, hikmah, dan kasih sayang.

Realita pandang dakwah terhadap manusia yang disamping memiliki beberapa kelebihan, ia juga memiliki berbagai macam kekurangan dan keterbatasan. Ia sering kali mengalami kegagalan mengomunikasikan dirinya ditengah-tengah masyarakat sehingga terbelenggu dalam lingkaran problem yang mengggangu jiwanya. Oleh karena itu dakwah harus memandang setiap mitra dakwah sebagai manusia dengan segala problematikanya. Pendekatan psikologis ini terutama bagi mereka yamg memerlukan pemecahan masalah rohani, baik dengan bimbingan dan penyuluhan maupun dengan metode-metode yang lain. ${ }^{20}$ Pendekatan psikologis merupakan pendekatan yang menitik beratkan pada perasaan setiap individu, berdakwah dengan mencoba mengtahui kondisi mad'u melalui perasaan dan tingkah laku. Sebagaimana telah disebutkan di atas tentang pendekatan psiokologi.

Dalam masyarakat yang terhimpit ekonomi, tentunya dakwah dengan pendekatan ekonomi lebih mengenai daripada pendekatan psikologis semata. Demikian juga dengan pendekatan ekonomi kepada mitra dakwah yang meliputi kecemasan batin akan merupakan kesalahan jika didekati dengan ekonomi semata, sebab mereka seharusnya, didekati secara psikologis. ${ }^{21}$

Beberapa strategi berikut ini adalah alternatif mengembangkan dakwah agar dapat menyelesaikan beberapa problem, yaitu:

${ }^{20}$ Moh. Ali Aziz, Op.cit, h. 147-148.

${ }^{21}$ Moh. Ali Aziz, Ilmu Dakwah, (Jakarta: Kencana, 2004), Cet. Ke-1, h. 143-144 
Dakwah harus dimulai dengan mencari "Kebutuhan Masyarakat". Kebutuhan dimaksudkan bukan hanya kebutuhan sacara objektif memang memang memerlukan pemenuhan, tetapi juga kebutuhan yang dirasakan oleh masyarakat setempat perlu mendapat perhatian. ${ }^{22}$ Kebutuhuan yang dimaskud dapat di ketahui melalui pendekatan psikologis, dengan mengetahui detail dari setiap individu masyarakat.

Dakwah dilakukan secara terpadu, dengan pengertian bahwa berbagai aspek kebutuhan masyarakat di atas dapat terjangkau oleh program dakwah, melibatkan berbagai unsur yang ada dalam masyarakat dan penyelenggaraan program dakwah itu sendiri merupakan rangkaian yang terpisah-pisah. ${ }^{23}$ Dakwah terpadu dapat juga diartikan dengan dakwah yang terstruktur yang melibatkan seluruh anggota masyarakat, gerakan atau organisasi tertentu. Seperti yang telah dicontohkan oleh berbagai gerakan dakwah struktural.

Dakwah dilakukan dengan pendekatan partisipatori dari bawah. Dimaksudkan bahwa ide yang ditawarkan mendapatkan kesepakatan masyarakat atau merupakan ide masyarakat itu sendiri, memberi peluang bagi keikutsertaan masyarakat dalam perencanaan dan keterlibatan mereka dalam pelaksanaan program dakwah. ${ }^{24}$ Dalam hal ini pendekatan yang dilakukan adalah pendekatan kultural.

Dakwah dilaksanakan melalui proses sistematika pemecahan masalah. Artinya, program dakwah yang dilakukan masyarakat sejauh mungkin diproses menurut langkah-langkah pemecahan masalah. Dengan demikian, masyarakat dididik untuk bekerja secara berencana, efisien dan mempunyai tujuan yang jelas. ${ }^{25}$

Dakwah memanfaatkan teknologi yang sesuai dan tepat guna. Maksudnya adalah bahwa masukan teknologi dalam pengertian "perangkat lunak" maupun "perangkat keras" yang ditawarkan harus sesuai dengan kebutuhan masyarakat, terjangkau oleh pengetahuan dan keterampilan yang dimiliki masyarakat dan sekaligus dapat mengembangkan pengetahuan dan keterampilan, dapat meningkatkan produktifitas dan tidak mengakibatkan pengangguran. ${ }^{26}$

Program dakwah dilaksanan melalui tenaga da'i yang bertindak sebagai motivator, baik dilakukan oleh tenaga terlatih dari lembaga atau organisasi masyarakat yang berpartisipasi maupun dari luar daerah yang adaptif. 27

Program dakwah itu didasarkan atas asas swadaya dan kerja sama masyarakat. Dimaksudkan bahwa pelaksanaan program dakwah harus berangkat dari kemampuan diri sendiri dan merupakan kerja sama dari potensi-potensi yang ada, dengan demikian setiap bantuan dari pihak luar hanya dianggap sebagai pelengkap dari kemampuan dan potensi

\footnotetext{
22 Muhammad Sulthon, Op.cit, h. 35

${ }_{23}$ Muhammad Sulthon, Ibid, h. 35

24 Muhammad Sulthon, Ibid, h. 36

${ }^{25}$ Muhammad Sulthon, Ibid, h. 36

26 Muhammad Sulthon, Ibid, h. 36

27 Muhammad Sulthon, Ibid, h. 37
} 
yang sudah ada. Dakwah kultural melibatkan kajian antar disiplin ilmu dalam rangka meningkatkan serta memberdayakan masyarakat. Aktivitas dakwah kultural meliputi seluruh aspek kehidupan, baik yang menyangkut aspek sosial-budaya, pendidikan, ekonomi, kesehatan, alam sekitar dan lain-lain. Keberhasilan dakwah kultural ditandai dengan teraktualisasikan dan terfungsikannya nilai nilai Islam dalam kehidupan individu dan komunal. 28

Dari seluruh strategi yang di jelaskan diatas merupakan cara yang dapat diterpakan dalam masyarakat. Dalam buku Ilmu Dakwah karya Rini Setiawati, bahwa pendekatan dakwah adalah penentuan strategi dan pola dasar dan langkah dakwah yang didalamnya terdapat metode dan teknik untuk mencapai tujuan dakwah.29 Jadi, strategi yang dijelaskan diatas adalah bagian dari pendekatan dakwah itu sendiri.

\section{Jama'ah Tabligh \\ Pengertian}

Jama'ah Tabligh merupakan sekelompok atau segolongan kaum yang menyeru kepada yang ma'ruf dan mencegah dari yang mungkar, menyampaikan (tabligh) seruan Allah dengan landasan iman (laillaha ila llah). Agar iman tertanam dalam setiap diri dan tercipta lah rahmatan lil alamin yang dilandasi oleh Al-Qur'an dan hadits. Jama'ah Tabligh adalah jama'ah yang sangat intens melakukan dakwah. 30

Maulana Muhammad Ilyaz rahmatullah alaih ketika melulai kegiatan dakwah tabligh ini mengatakan "Aku tidak memberikan nama apa pun terhadap usaha ini. Tetapi, seandainya aku memberinya nama, tentu aku menamakannya 'gerakan iman'." Beliau menyadari bahwa memberikan suatu nama khusus pada kegiatan ini berarti membuat pengelompokan baru pada ummat. Ada umat yang aggota dan yang bukan anggota.Sedangkan dakwah dan tabligh adalah suatu amal ibadah seperti shalat, puasa, dzikir, dan sebagainya.Sebagaimana dalam ibadah-ibadah lain tidak ada pengelompokan dan keanggotaan (misalnya kelompok ahli shalat, ahli puasa dan lain-lain) demikian pula halnya dengan dakwah tablgih.Selain hal itu, dakwah adalah tanggung jawab setiap individu ummat ini yang harus mereka tunaikan tanpa kecuali. Bila bentuk satu kelompok dakwah, tentu akan timbul bahwa dakwah adalah tugas anggota kelompok dakwah saja. Dengan berbagai pertimbangan itu Maulana Ilyaz tidak memberikan nama terhadap usaha dakwah tablgih.

Sedangkan "Jama'ah Tabligh" hanyalah sebutan untuk memudahkan saja.Sebutan tersebut bukan berarti ada anggota dan ada yang bukan anggota. Orang-orang mengikuti program keluar selama beberpa hari, setelah selesai akan kembali ketempat tinggalnya dan menjalankan aktifitas sebagaimana biasa, di tambah dengan usaha untuk berdakwah kepada orang-orang di sekitarnya.

"Jaulah" dalam bahasa Arab berarti keliling."Jaulah" sendiri sebenarnya adalah satu program yang dilakukan setiap hari oleh jama'ah yang sedang keluar.Program serupa diadakan juga seminggu sekali di rumah-rumah sekitar

\footnotetext{
28 Muhammad Sulthon, Ibid, h. 37

29 Rini Setiawati, Op.cit, h. 68

${ }^{30}$ Khusniati Rofiah, Op.cit, h. 78
} 
masjid sendiri. Satu rombongan terdiri dari lima sanpai sepuluh orang mendatangi tiap-tiap rumah, menyampaikan pentingnya iman, amal shaleh, dan mengundang laki-laki penghuni rumah mengikuti program muzakarah dan kultum di masjid. Program ini biasanya dilakukan setelah Ashar hingga menjelang Maghrib. ${ }^{31}$

Dari penjelasan diatas Jama'ah Tabligh bukan lah nama dari gerakan ini, namun Jama'ah Tabligh hanyalah sebutan yang berasal dari masyarakat untuk memudahkan mengingat, keberadaan gerakan yang menyampaikan (tabligh) agama kepada ummat seluruh alam. Karena awal mula gerakan ini dibuat oleh Maulana Ilyaz rahmatullah alaih di Mewat, India saat itu tidak diberi nama. Jika gerakan ini diberi nama niscaya beliau akan menamai dengan gerakan Iman untuk membentuk sifat yakin kepada Allah Swt.

\section{Pendekatan Dakwah Jama'ah Tabligh}

Pendekatan yang dilakukan Jama'ah Tabligh adalah dengan cara ber-Jaulah (silaturahmi) mengunjungi saudara muslim dari rumah ke rumah dan membuat ceramah agama atau majlis penerangan (bayan) tentang pentingnya iman dan amal shalih di masjid.

1. Jaulah (Silaturahmi)

Jaulah sebagai tulang punggung dakwah, dan dakwah adalah tulang punggung agama. Sesuatu tanpa tulang punggung tak akan bisa berdiri tegak. Dakwah adalah semua amal Jaulah, sebagaimana shalat gerakannya berbeda-beda. Mulai dari Jaulah umumi32, jaulah khusyusi33, jaulah usuli34, jaulah ta'lim $^{35}$ dan jaulah tasykil. ${ }^{36}$ Jaulah adalah mengunjungi saudara-saudara kita yang lain. ${ }^{37}$ Kelompok Jaulah terdiri dari dua bagian, yaitu :

Kelompok di dalam masjid adalah : Dzakkirin, tugasnya berdzikir dan berdo'a dengan khusyu menangis memohon hidayah, hingga jama'ah yang diluar telah kembali, Muqararrar, tugasnya mengulang-ulang pembicaraan iman dan amal shalih (taqrir), Mustami' Tawajjuh mendengar pembicaraan taqrir, dan Istiqbal, menyambut orang yang datang ke masjid, lalu mempersilahkan duduk dalam majelis taqrir. Menunggu dengan penuh fikir dan kerisauan kepada saudaranya yang belum datang ke masjid.

Dan kelompok di luar masjid adalah : Dalil, sebagai petunjuk jalan, sebaiknya dalil adalah warga setempat, untuk menunjukan mana rumah non muslim, ulama, dan ahli masjid atau orang yang belum shalat berjama'ah di masjid, Mutakallim, sebagai juru bicara Rasulullah Saw, Makmur, tugasnya berdzikir (dalam hati), dan mengantarkan orang-orang yang di tasykil ke

31 Mulwi Ahmad Harun Al-Rosyid, Meluruskan Kesalahpahaman Terhadap Jaulah (Jama'ah Tabligh), (Magetan : Pustaka Haromain, 2004), Cet. Ke-2, h.22

32 Jaulah umumi adalah silaturahmi kepada orang-orang awam, masyarakat yang belum mengenal usaha dakwah.

33 Jaulah khusyusi adalah silaturahmi kepada masyarakat golongan tertentu, seperti : khususi kepada tokoh (Umaro), kepada Ulama, kepada Kaum Dhuafa'.

${ }^{34}$ Jaulah usuli adalah silaturahmi untuk mengajak pekerja dakwah (da'i) yang sudah niat dan mencatatkan nama untuk keluar di jalan (khuruj fii sabilillah) Allah SWT.

3535 Jaulah ta'lim adalah silaturahmi ke rumah-rumah saudara muslim untuk mengajak mendengarkan ta'lim yang sedang berlangsung di masjid.

36 An Nadhr Muhammad Ishaq Shahab, Op.cit, h. 158

2004), Cet. Ke-1, h. 55

37 Sa'ad Bin Ibrahim Syilbi, Dalil-Dalil Dakwah Dan Tabligh, (Bandung :Pustaka Ramadhan, 
masjid, dan Amir Jaulah, bertanggung jawab terhadap rombongan Jaulah. Jika ada yang melanggar tertib, amir mengucapkan subhanallah dan masingmasing mengoreksi dirinya bukan melihat orang lain. Jika masih tidak tertib juga maka amir member targhib (peringatan) dan berhak memutuskan, apakah jualah dilanjutkan atau kembali ke masjid. ${ }^{38}$

Jaulah bertujuan untuk mengekalkan hidayah dalam diri seorang yang melaksanakan jaulah (silaturahmi) kepada saudara muslim dari rumah ke rumah dan mengekalkan hidayah kepada seluruh makhluk. Dari tujuan inilah dapat diketahui bahwa tujuan di buatnya usaha dakwah dengan berjaulah (silaturahmi) merupakan amalan yang besar, untuk mengajak manusia sama-sama taat kepada Allah Swt dan mengamalkan agama secara sempurna (kaffah). Waktu Jaulah yaitu ba'da shalat Ashar, kecuali pada bulan Ramadhan dilakukan setelah dan sebelum shalat Ashar. Adab-adabnya menyampaikan pentingnnya adab-adab Jaulah, diantaranya :

a. Pentingnya agama dalam kehidupan manusia dan pentingnya dakwah

b. Usaha para Nabi A.S terutama usaha dakwah Rasulullah Saw. Maksud Jaulah dan keutamaannya.

c. Adab-adab keluar untuk Jaulah

d. Sampaikan Pentingnnya agama dalam kehidupan manusia.

e. Menundukan pandangan ketika ber-Jaulah.

f. Berjalan di sebelah kanan

g. Tidak berbicara kepada orang dungu, perempuan, orang yang sedang memegang senjata, orang yang sedang memikul beban berat, orang yang sedang berjalan secara terburu-buru, orang yang sedang berjalan dengan istrinya, atau orang yang tidak ada hubungan dengan Islam (non muslim)

h. Keluar dari masjid dengan kaki kiri kemudian berdo'a memohon hidayah.

i. Membaca istighfar ketika semua nya kembali ke masjid. ${ }^{39}$

2. Bayan (Majlis Penerangan)

Bayan bukan maksud, tetapi bagaimana setiap da'i ada kerisauan dan fikir ummat dalam hati. Usaha ini bukan kabilyat (kelebihan), tetapi kabulyat (kekurangan) amal oleh Allah Swt banyak orang yang beranganggapan, bahwa sekedar menyampaikan itu adalah tabligh. Ini adalah pemahaman yang keliru. Tabligh adalah meyampaikan agama kepada orang lain sesuai dengan maslahat dan kemampuan diri, dengan harapan orang lain mau menerimanya. Seperti inilah dakwah dan tabligh yang dibawa oleh Anbiya A.S. Pekerjaan utama dalam usaha ini adalah kerja hati, yakin dengan senantiasa kembali (tawajjuh) kepada Allah Swt memohon pertolongan dan berserah diri kepada-Nya serta memutuskan harapan kepada selain-Nya. Setelah itu kerja kaki dan tangan dengan usaha sungguh-sungguh. Dan yang terakhir adalah kerja lisan, hendaknya memberi bayan dan penerangan ditempatkan pada bagian yang paling sedikit. Adab-adab ketika bayan:

a. Semua ucapan mengarah kepada kebaikan

\footnotetext{
38 An Nadhr Muhammad Ishaq Shahab, Op.cit, h. 159-160

39 Sa'ad bin Ibrahim Syilbi, Op.cit, h. 62
} 
b. Menghindari pembicaraan yang sia-sia

c. Pembicaraan tidak mengarah kepada kebatilan.

d. Tidak mengarah kepda kekejian, mencela, atau melaknat.

e. Pembicaraan tidak mengandung penghinaan atau melecehkan.

f. Tidak mencemarkan nama baik atau rahasia seorang muslim.

g. Pembicaraan tidak mengandung permusuhan atau ghibah.

h. Pembicaraan tidak mengandung kebohongan.

i. Perkataannya jelas, tidak bertele-tele dan mudah dipahami.

j. Tidak bercanda atau membuat orang lain tertawa.

k. Tidak menunjukan kesombongan agar orang lain menganggapnya sebagai orang fasih.

1. Tidak mengundang perdebatan sengit.

m. Mengulang-ulang pembicaraan penting untuk diketahui.

n. Menyampaikan kabar gembira.

o. Mengetahui kondisi (ahwal) seorang atau masyarakat sehingga tidak membuat mereka bosan atau menimbulkan fitnah.

p. Tidak memuji orang-orang fasik.

q. Mubayyin atau mustami' berhadapan langsung dan duduk dengan rapat.

r. Mengabarkan kehidupan akhirat, alam kubur, mahsyar, Jannah dan neraka. 40

3. Ta'lim wat ta'lum

Ta'lim wat ta'lum adalah belajar dan mengajar, yang bertujuan untuk memasukan nur kalamullah (cahaya ilmu dan pemahaman ayat al-Qur'an) dan nur sabda Rasulullah Saw (cahaya ilmu dan pemahaman dari hadits dan sunnah) untuk meningkatkan gairah beramal. ${ }^{41}$ Diantara keutamaan ta'lim wat ta'lum, adalah :

a. Mendapat sakinah dan ketenangan jiwa

b. Dicucuri rahmat oleh Allah Swt

c. Dikelilingi para malaikat bershaf-shaf sampai di ‘arsy

d. Nama kita dibangga-banggakan oleh Allah Swt di hadapan majelis para malaikat.

e. Menghancurkan seratus majelis lali bila dilakukan dimasjid dan menghancurkan empat puluh majelis bila dilakukan di rumah. ${ }^{42}$

Kerugian bila $\mathrm{ta}^{\prime}$ lim ditinggalkan :

a. Beramal dengan mengikuti hawa nafsu

b. Tidak mengetahui nilai akhirat

c. Syetan berdakwah dalam rumah, sehingga maksiat merajalela. 43

Adab-adab ta'lim dibagi dua :

a. Adab zhahiriah :

40 An Nadhr Muhammad Ishaq Shahab, Khuruj fii sablilillah : Sarana Tarbiyyah Ummat Dalam Rangka Membentuk Sifat Imaniyah, (Bandung : Pustaka Ramadhan, 2007), Cet. ke-7 , Jilid 1, h. 164-171

41 An Nadhr Muhammad Ishaq Shahab, Ibid, h. 188

42 An Nadhr Muhammad Ishaq Shahab, Ibid, h. 188

43 An Nadhr Muhammad Ishaq Shahab, Ibid, h. 189 
1) Berwudhu, lalu duduk rapat-rapat dengan posisi iftirasy menghadap kiblat dengan tawajjuh kepada Allah Swt, dan memakai wangiwangian.

2) Membaca dengan jelas dan teratur, bila perlu di ulangi sampai tiga kali dan tidak menambah dengan kata-kata sendiri. Bacalah yang tertulis dalam kitab Fadhail A'mal.

3) Apabila mendengar nama Rasulullah Saw disebut, disunnahkan bershalawat, apabila nama sahabat Ra disebut, ucapkan radiallahu anhum, dan apabila disebut nama orang-orang yang dilaknat maka ucapkanlah laknatullah alaihi. Hendaknya diucapkan dengan suara rendah, agar tidak menganggu kekhusyuan majlis.

4) Bila mendengar kabar gembira tentang pahala dan Jannah, ucapkanlah tasbih, tahmid, dan takbir, semoga Allah Swt menganugerahkan kepada diri kita.

5) Tidak meniggalakan majelis seblum selesai. Syetan berusaha bagaimana kita berhajat keluar dari majelis, padahal saat itu Allah Swt akan menganugerahkan hidayah.

6) Buatlah jau; ah ta'lim agar pikir manusia di luar masjid bisa berubah. ${ }^{4}$ b. Adab Batiniah :

1) Ta'zhim wal ihtiram (mengagungkan dan memuliakan)

2) Tashdiq wal yaqin (membenarkan dan memuliakan)

3) Ta'atsur bil qalbi (berkesan dalam hati)

4) Niatul amal wattabligh (niat amal dan menyampaikan). ${ }^{45}$

\section{Simpulan}

Berdasarkan hasil penelusuran dan pembahasan tentang Pendekatan Dakwah Jama'ah Tabligh dalam meningkatkan Ketaatan beragama, dapat ditarik kesimpulan bahwa:

Pendekatan Dakwah Jama'ah Tabligh dalam meningkatkan ketaatan beragama masyarakat yang berada memiliki peranan yang signifikan. pendekatan dakwah yang dilakukan Jama'ah Tabligh diantaranya adalah dengan pendekatan psikologis, pendekatan pendidikan dan pendekatan budaya dan lain-lain. pendekatan diatas merupakan pendekatan yang cocok digunakan untuk masyarakat Indonesia. Dengan demikian pendekatan dakwah yang dilakukan Jama'ah Tabligh adalah :

Pendekatan psikologis, pendekatan ini dilakukan oleh Jama'ah Tabligh dengan cara ber-jaulah (silaturahim) dari rumah ke rumah. Upaya dengan mendatangi langsung objek dakwah $\left(\right.$ mad' $\left.^{\prime} u\right)$ mengajak dengan hikmah, dari hati ke hati, membujuk hati masyarakat untuk sama-sama taat kepada Allah dengan mengikuti cara Rasulullah Saw. Jama'ah Tabligh dimulai pendekatan psikologis masyarakat dengan mengenalkan diri (ta'aruf), merendahkan hati (ta'aluq) kepada mad'u, membicarakan kebesaran Allah (targhib), dan terakhhir mengajak untuk sama-sama beramal shalih (tasykil). Namun pendekatan ini belum sepenuhnya berhasil karena Jama'ah Tabligh melupakan salah satu pendekatan dakwah yaitu pendekatan budaya, karena keberagaman budaya, sedangkan Jama'ah Tabligh

\footnotetext{
${ }^{44}$ An Nadhr Muhammad Ishaq Shahab, ibid, h. 189

45 An Nadhr Muhammad Ishaq Shahab, ibid, h. 189
} 
menggunakan pendekatan budaya yang sama dimana Rasulullah Saw dilahirkan yaitu di Makkah.

Pendekatan pendidikan, dengan pendekatan untuk menginformasikan pengetahuan akan agama. Upaya yang dilakukan oleh Jama'ah tabigh, dengan menggunakan pendekatan pendidikan yaitu dengan mengadakan bayan (ceramah agama) tentang pentingnya iman dan amal shalih, dan mengadakan $t a^{\prime} l i m$ dimasjid.

Pendekatan budaya, dalam pendekatan ini Jama'ah Tabligh belum dapat menyesuaikan diri dengan budaya masyarakat yang beragam, dimulai dari penampilan yang mencontoh Nabi, menggunakan gamis atau jubah, menggunakan sorban. Sedangkan masyarakat belum terbiasa dengan penampilan dan kebiasaan yang Jama'ah Tabligh lakukan. Hal ini yang menjadi salah satu faktor belum berhasilnya pendekatan Jama'ah Tabligh dalam meningkatkan ketaatan beragama masyarakat.

Dengan upaya yang dilakukan Jama'ah Tabligh untuk meningkatkan ketaatan beragama masyarakat, sesuai dengan Pendekatan Dakwah yang dijadikan teori yang dikemukakan oleh Drs. Sahudi Siroj dalam buku Ilmu Dakwah karya Rini Setiawati hanya menggunakan tiga pendekatan yaitu pendekatan psikologi, pendekatan pendidikan dan pendekatan budaya. Jadi, Jama' ah Tabligh dengan berjaulah (silaturahim) mengunjungi rumah-rumah saudara muslim, mengadakan bayan (ceramah agama) dan ta'lim, membuat suasana agama timbul, masyarakat mendapatkan pengetahuan agama, terutama tentang iman, amal shalih, dan usaha atas iman dan amal shalih atau usaha atas agama.

Namun, karena ada pendekatan yang dilupakan Jama'ah Tabligh dalam upaya meningkatkan ketaatan beragama masyarakat, yaitu pendekatan budaya. Maka terjadi Pro dan kontra terhadap Jama'ah Tabligh, dan ini merupakan ujian bagi Jama'ah Tabligh. Diantaranya ada yang menggap upaya Jama'ah Tabligh dengan ber-jaulah dan majlis penerangan (bayan) bukan amalan yang dilakukan oleh Rasulullah Saw, tetapi amalan orang India, Pakistan, dan Bangladesh, sebagaimana awal kerja dakwah ini berkembang disana. Ada pula yang menganggap usaha ini sudah tidak sesuai lagi dilaksanakan pada zaman ini, karena perkembangan teknologi informasi yang berkembang cepat dan praktis. Oleh sebab itu masyarakat mengganggap usaha yang dilakukan Jama'ah Tabligh ini sia-sia saja dan membuang-buang waktu di zaman yang serba modern ini.

\section{Referensi}

An Nadhr Muhammad Ishaq Shahab, Khuruj fii sablilillah: Sarana Tarbiyyah Ummat Dalam Rangka Membentuk Sifat Imaniyah, (Bandung : Pustaka Ramadhan, 2007), Cet. ke-7, Jilid 1

Asep Saeful Muhtadi, Agus Ahmad Safei, Metodologi Penelitian Dakwah, (Bandung : Pustaka Setia, 2003), Cet. Ke-1

Dessy Anwar, Kamus Lengkap Bahasa Indonesia Terbaru, (Surabaya : Amelia)

Khusniati Rofiah, Dakwah Jama'ah Tabligh \& Eksistensinya Di Mata Masyarakat, (Ponorogo : STAIN Press, 2010), Cet. Ke-1

Moh. Ali Aziz, Ilmu Dakwah, (Jakarta : Kencana, 2009), Cet. Ke-2

Muhamad Bisri Mustofa, Hukum Nafkah Terhadap Keluarga pada Gerakan Dakwah Jama'ah Tabligh, Jurnal Nizham, Vol. 7, No. 1 (2019) 
Muhammad Sulthon, Desain Ilmu Dakwah Kajian Ontologis, Epistimologi dan Aksiologis, (Yogyakarta : Walisongo Press, 2003)

Mulwi Ahmad Harun Al-Rosyid, Meluruskan Kesalahpahaman Terhadap Jaulah (Jama'ah Tabligh), (Magetan : Pustaka Haromain, 2004), Cet. Ke-2

Rini Setiawati, Ilmu Dakwah, (Bandar Lampung : PUSIKAMLA, 2009), Cet. Ke-1

Sa'ad Bin Ibrahim Syilbi, Dalil-Dalil Dakwah Dan Tabligh, (Bandung :Pustaka Ramadhan, 2004), Cet. Ke.1

Samsul Munir Amin, Ilmu Dakwah, (Jakarta : Amzah, 2009), Cet. Ke-1 